\title{
Effect of Incremental Utilization of Unground Sea Sand Ore on the Consolidation and Reduction Behavior of Vanadia-Titania Magnetite Pellets
}

\author{
Zhenxing Xing ${ }^{1,2}$, Gongjin Cheng ${ }^{1,2}$, Zixian Gao ${ }^{1}$, He Yang ${ }^{1,2}$ and Xiangxin Xue ${ }^{1,2, *}$ \\ 1 School of Metallurgy, Northeastern University, Shenyang 110819, China; zhxing_x@163.com (Z.X.); \\ successking123@gmail.com (G.C.); $1710509 @$ @stu.neu.edu.cn (Z.G.); yangh@smm.neu.edu.cn (H.Y.) \\ 2 Liaoning Key Laboratory of Recycling Science for Metallurgical Resources, Shenyang 110819, China \\ * Correspondence: xuexx@mail.neu.edu.cn
}

Citation: Xing, Z.; Cheng, G.; Gao,

Z.; Yang, H.; Xue, X. Effect of

Incremental Utilization of Unground Sea Sand Ore on the Consolidation and Reduction Behavior of Vanadia-Titania Magnetite Pellets. Metals 2021, 11, 269. https:// doi.org/10.3390/met11020269

Academic Editor: Fernando Castro Received: 19 December 2020

Accepted: 30 January 2021

Published: 5 February 2021

Publisher's Note: MDPI stays neutral with regard to jurisdictional claims in published maps and institutional affiliations.

Copyright: (c) 2021 by the authors. Licensee MDPI, Basel, Switzerland. This article is an open access article distributed under the terms and conditions of the Creative Commons Attribution (CC BY) license (https:// creativecommons.org/licenses/by/ $4.0 /$ )

\begin{abstract}
In the iron and steel industry, improving the usage amount of New Zealand sea sand ore as a raw material for ironmaking can reduce the production costs of iron and steel enterprises to a certain extent. In this paper, New Zealand sea sand ore without any grinding pretreatment was used as a raw material, oxidized pellets were prepared by using a disc pelletizer, and the effect of sea sand ore on the performance of green pellets and the metallurgical properties of oxidized pellets was investigated. The effects of sea sand ore on the compressive strength, falling strength, compressive strength of oxidized pellets, and reduction performance were mainly investigated. X-Ray Diffraction (XRD) patterns and Scanning Electron Microscope (SEM) analysis methods were used to discuss the influence of sea sand ore on the microstructure of the pellets' oxidation and reduction process. As the amount of sea sand ore used increased, the compressive strength of green pellets was gradually decreased, and the falling strength of green pellets and the compressive strength of oxidized pellets were gradually increased. When the amount of sea sand ore used was $40 \%$, the reduction swelling index of pellets was $16.31 \%$. The increase of sea sand ore used made the reduction of pellets suppressed and the reduction rate decreased. When the amount of sea sand ore used increased to $40 \%$, the reduction degree of sea sand ore pellets was only $60.06 \%$. The experimental results in this paper provide specific experimental data for the large-scale application of New Zealand sea sand ore in the blast furnace ironmaking process.
\end{abstract}

Keywords: sea sand ore; vanadia-titania magnetite pellets; compressive strength; reduction swellability; reduction degree

\section{Introduction}

The research and utilization of complex iron ore resources by researchers can not only alleviate the plight of iron ore resource shortage in iron and steel enterprises, but also save a lot of raw material costs for iron and steel enterprises to a large extent $[1,2]$. Therefore, the development and utilization of non-high-quality vanadia-titania magnetite resources have become a common concern of scholars and steel companies from all over the world [3,4].

Sea sand ore is a kind of complex iron ore resource with titania magnetite as the main mineral phase formed by the erosion of rivers, waves, tides, and ocean currents in coastal areas [5-8]. It is also a globally recognized resource of vanadia-titania magnetite that is difficult to beneficiate and difficult to smelt [9]. There are mineral deposits in New Zealand, Australia, Japan, the Philippines, and Indonesia. The reserves are very rich, easy to mine, and low cost $[10,11]$. The iron-bearing sea sand mineralization process represented by the New Zealand sea sand ore is mainly due to the eruption of volcanic rock, which was formed by cooling in air or sea water, and then due to the erosion of air and sea water, the sea sand deposits in the coastal area of New Zealand were formed [12,13]. Wright et al. conducted basic research on New Zealand sea sand ore, and it was shown that the 
main phase of sea sand ore was titanomagnetite, aluminum spinel, and a small amount of ilmenite [5-7]. The relevant literature reported that the total iron grade of sea sand ore was about $60 \%$, the titanium dioxide content was about 7-9\%, and it also contained relatively high amounts of $\mathrm{V}_{2} \mathrm{O}_{5}, \mathrm{Al}_{2} \mathrm{O}_{3}, \mathrm{~K}_{2} \mathrm{O}, \mathrm{Na}_{2} \mathrm{O}$, and other difficult to sinter minerals [14-16].

The New Zealand sea sand ore is a vanadia-titania magnetite with a compact structure and complex mosaic distribution of useful metal minerals. Compared with other iron ores, sea sand ore particles are mostly spherical, with a smooth surface, coarser particle size, small specific surface area, small wet capacity, and poor hydrophilicity. Ball milling performance and pellet-forming performance are also poor. Therefore, as a raw material for ironmaking, it is difficult to agglomerate, and it is limited in blast furnace smelting $[17,18]$. $\mathrm{Lv}$ et al. studied the influence of sea sand ore on the quality of sinter, and found that with the increase in the proportion of sea sand ore, the low-temperature reduction degradation performance of sinter became worse and the reducibility became better, and the amount of sea sand ore used should be controlled at 5-10\% [19]. Hu et al. studied the influence of sea sand ore on the sintering process, and suggested that the proportion of sea sand ore in the sintered mixture should be strictly controlled within $20 \%$ [20].

Many scholars have conducted a series of studies on the reduction characteristics of sea sand ore. Park E. et al. studied the phase transition of sea sand ore in the process of gas-based reduction $\left(\mathrm{CO}\right.$ or $\left.\mathrm{H}_{2}\right)$ [21-23]. Longbottom R. J. et al. analyzed the phase transformation of sea sand ore during the reduction process, and considered the formation of the bonding phase in the compact and the increase in the compact strength were mainly affected by the reduction temperature [24-26]. Sun et al. proposed adopting non-blast furnace ironmaking to treat sea sand ore by using coal-based direct reduction-magnetic separation to recover iron and titanium from ilmenite, and conducted related research to verify the feasibility of this method [27-29].

The pellet is regarded as an excellent raw material for ironmaking because of its advantages such as high grade, good reducibility, and uniform particle size. Due to the regular particle shape of sea sand ore, the surface is smooth and dense, the particle size is relatively coarse, and the ball-forming performance is poor. Therefore, the application of sea sand ore in blast furnace ironmaking is mostly used as an auxiliary material to prepare sinter, and there are few related studies on the preparation of oxidized pellets with sea sand ore.

To reduce the production cost of iron and steel enterprises, this paper prepared the coarse-grained sea sand ore into oxidized pellets without any pretreatment. The effects of the amount of sea sand ore used on the falling strength, compressive strength, reduction swelling index, and reduction degree of pellets were investigated, and the change laws and influencing factors were analyzed. On this basis, the effect of the amount of sea sand ore used on the microstructure before and after the reduction of oxidized pellets was discussed by conducting x-ray diffraction (XRD) and scanning electron microscopeenergy dispersive spectroscopy (SEM-EDS) analysis of the oxidized pellets at different experimental conditions.

\section{Experimental}

\subsection{Raw Materials}

The pelletizing raw materials used in this experiment mainly included New Zealand sea sand ore (HS), Sijiaying (SJY), Yuantong-14 (YT-14), and bentonite. The experimental raw materials were quantitatively analyzed by atomic emission spectrometer (ICP-AES, Optima 8300DV; PerkinElmer, Waltham, MA, USA) and x-ray fluorescence (XRF, ZSXPrimus-II; Rigaku, Tokyo, Japan). The results are shown in Tables 1 and 2. It can be seen from Table 1 that the total iron content of sea sand ore was $58.36 \%$ and the content of $\mathrm{TiO}_{2}$ and $\mathrm{V}_{2} \mathrm{O}_{5}$ was $6.95 \%$ and $0.47 \%$, respectively, which belongs to a typical vanadia-titania magnetite. The experiment was mainly based on the principle of optimizing ore blending. Oxidized pellets were prepared from the above three raw materials to make use of the sea sand ore. 
Table 1. Chemical composition of the experimental raw materials (mass/\%).

\begin{tabular}{ccccccccccc}
\hline Compositions & $\mathrm{TFe}$ & $\mathbf{F e O}$ & $\mathbf{S i O}_{2}$ & $\mathbf{C a O}$ & $\mathbf{M g O}$ & $\mathrm{Al}_{2} \mathbf{O}_{3}$ & $\mathrm{TiO}_{2}$ & $\mathbf{V}_{\mathbf{2}} \mathbf{O}_{5}$ & $\mathbf{S}$ & $\mathbf{P}$ \\
\hline HS & 58.36 & 28.23 & 3.27 & 1.15 & 2.88 & 3.33 & 6.95 & 0.47 & 0.003 & 0.15 \\
SJY & 65.29 & 17.99 & 6.72 & 0.22 & 0.42 & 0.42 & 0.12 & 0.03 & 0.061 & 0.021 \\
YT-14 & 66.27 & 24.77 & 1.83 & 0.69 & 0.88 & 1.41 & 2.48 & 0.29 & 0.066 & 0.045 \\
\hline
\end{tabular}

Table 2. Chemical compositions of bentonite (mass/\%).

\begin{tabular}{ccccccc}
\hline Compositions & $\mathrm{SiO}_{2}$ & $\mathbf{C a O}$ & $\mathbf{M g O}$ & $\mathbf{A l}_{\mathbf{2}} \mathbf{O}_{3}$ & $\mathbf{N a}_{2} \mathbf{O}$ & $\mathbf{K}_{2} \mathbf{O}$ \\
\hline Content & 44.88 & 4.08 & 2.88 & 12.88 & 4.18 & 1.03 \\
\hline
\end{tabular}

\subsection{Characteristic Analysis of New Zealand Sea Sand Ore}

XRD (X'Pert Pro; PANalytical, Almelo, The Netherlands) was used to analyze the phase composition of the experimental raw materials, and the results are shown in Figure 1. Sea sand ore (HS) was mainly composed of hematite $\left(\mathrm{Fe}_{2} \mathrm{O}_{3}\right)$, magnetite $\left(\mathrm{Fe}_{3} \mathrm{O}_{4}\right)$, and ilmenite spinel $\left(\mathrm{Fe}_{2} \mathrm{TiO}_{4}\right)$. Titanium was mainly present in sea sand ore in the form of ilmenite spinel. The main phases in Sijiaying (SJY) were hematite $\left(\mathrm{Fe}_{2} \mathrm{O}_{3}\right)$, magnetite $\left(\mathrm{Fe}_{3} \mathrm{O}_{4}\right)$, and silica $\left(\mathrm{SiO}_{2}\right)$, while Yuantong-14 (YT-14) was mainly composed of the hematite $\left(\mathrm{Fe}_{2} \mathrm{O}_{3}\right)$, magnetite $\left(\mathrm{Fe}_{3} \mathrm{O}_{4}\right)$, and ilmenite oxide phases $\left(\mathrm{Fe}_{2.5} \mathrm{Ti}_{0.5} \mathrm{O}_{4}\right)$.

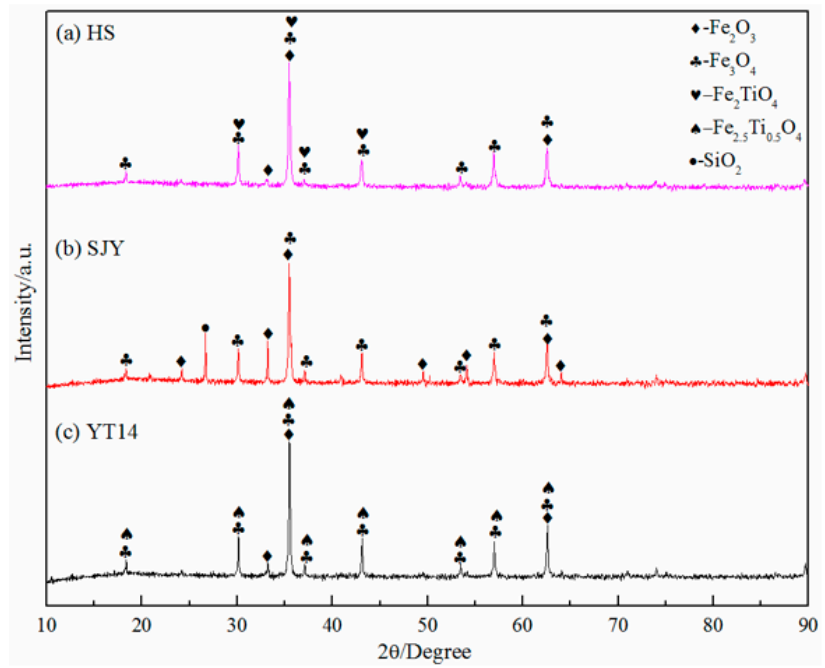

Figure 1. X-ray diffraction analysis pattern of experimental raw materials.

After putting the sea sand ore into an oven for drying treatment, its macroscopic morphology is shown in Figure 2a, and its microscopic morphology is shown in Figure 2b,c. An energy dispersive spectrometer (EDS) (Ultra Plus; Carl Zeiss GmbH, Jena, Germany) was used to analyze the chemical compositions. It can be seen from Figure 2 that the shape of the sea sand ore particles was relatively regular, showing a spherical or ellipsoidal shape; the texture of the particles was smooth and shiny; and the density was relatively high. These characteristics are not conducive to the preparation of oxidized pellets from the sea sand ore. The EDS analysis results were consistent with the XRD analysis. In addition, it was found that $\mathrm{P}$ in the sea sand ore existed in the form of calcium phosphate $\left(\mathrm{Ca}_{3}\left(\mathrm{PO}_{4}\right)_{2}\right)$.

A Mastersizer 3000 laser particle size analyzer (Mastersizer 3000; Malvern, UK) was used to analyze the particle size composition of the three raw materials, and the results are shown in Figure 3. It can be seen from the particle size distribution diagram that the particle size of the sea sand ore was coarsest, followed by Yuantong-14, and Sijiaying ore was the finest. Among them, the particle size distribution of the large part of the sea sand ore was about $144 \mu \mathrm{m}$, and the particle size of Sijiaying and Yuantong-14 was relatively fine, most of which were distributed around $52 \mu \mathrm{m}$ and $67 \mu \mathrm{m}$, respectively. 

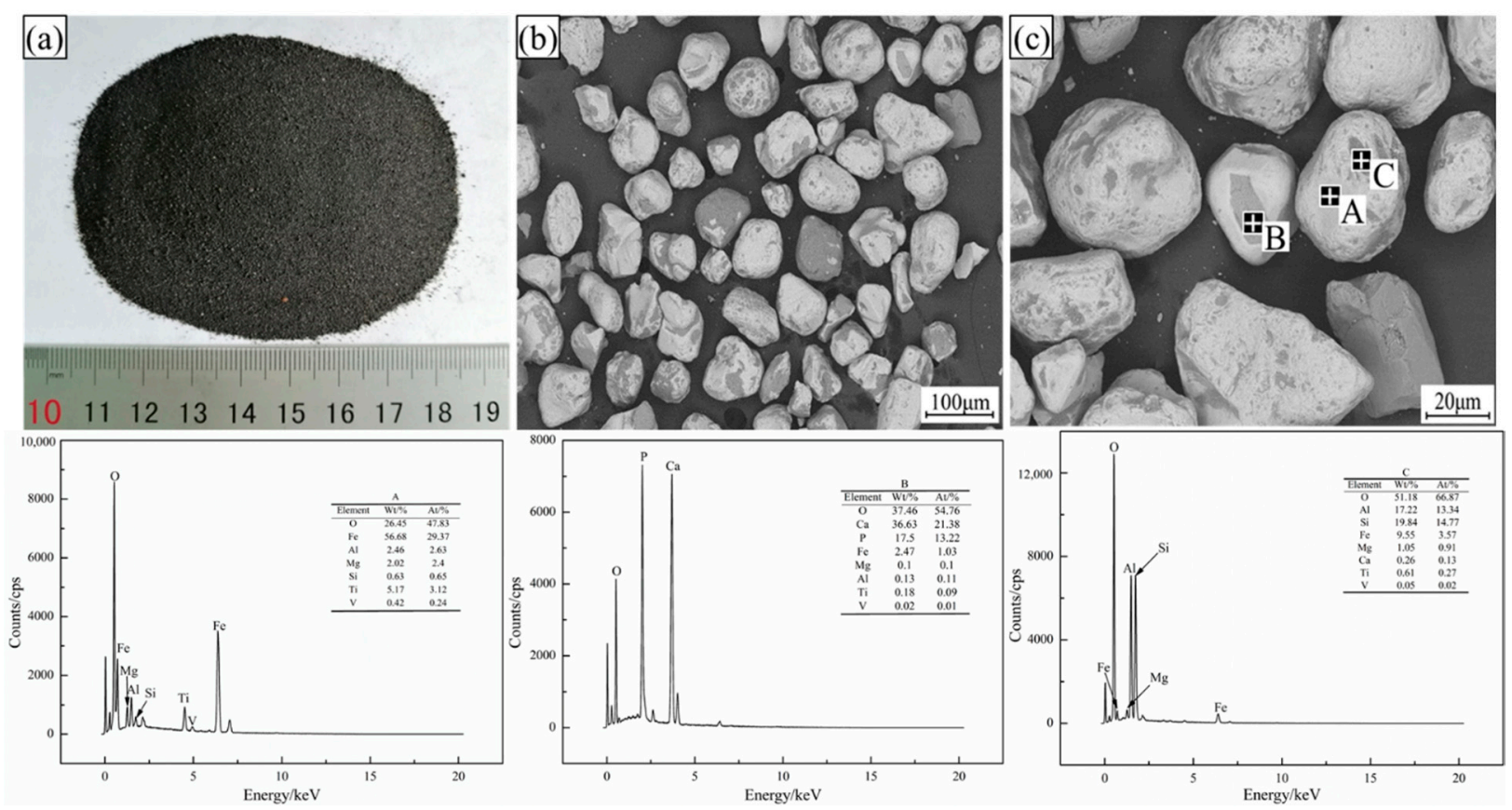

Figure 2. Structure of the sea sand ore: (a) Original state; (b) $200 \times$; (c) $500 \times$.

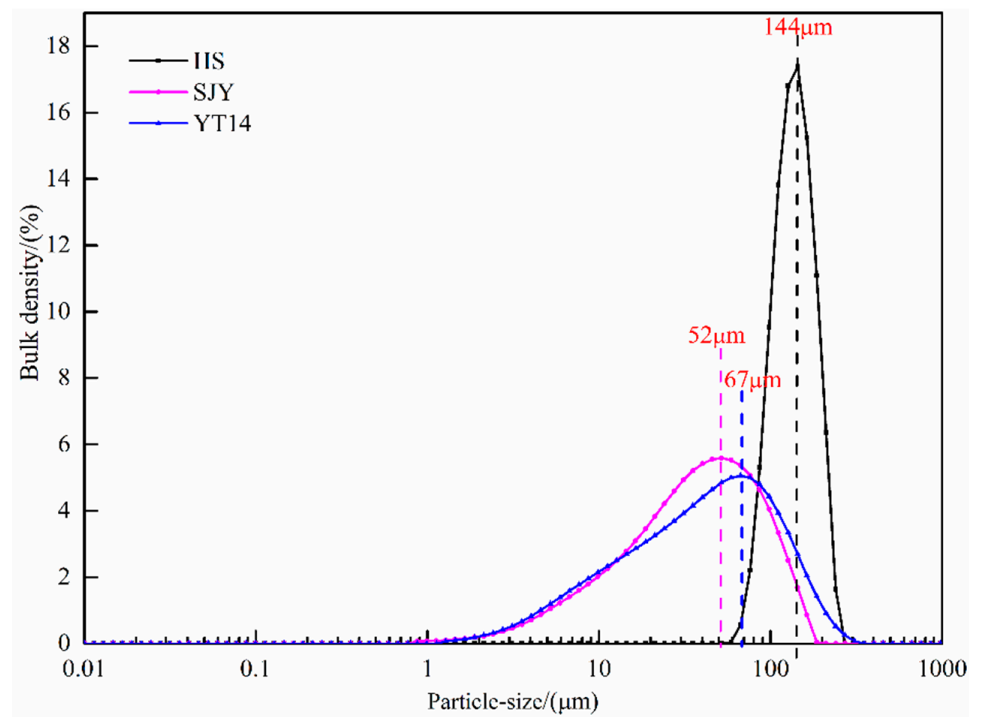

Figure 3. Particle size distribution of the experimental raw materials.

By using the NOVA-1200e specific surface area analyzer (NOVA-1200e; Quantachrome, Boynton Beach, FL, USA) and nitrogen adsorption Brunner-Emmet-Teller (BET) method, the specific surface area of the three raw materials used in the experiment was determined and analyzed to further characterize the surface condition of the raw material particles. The results are shown in Table 3. Among the three raw materials used in the experiment, the specific surface area of the sea sand ore was the smallest at only $0.3 \mathrm{~m}^{2} / \mathrm{g}$, the specific surface area of Yuantong- 14 was the second at $8.2 \mathrm{~m}^{2} / \mathrm{g}$, and the specific surface area of Sijiaying was the largest, reaching as high as $70.2 \mathrm{~m}^{2} / \mathrm{g}$. The small specific surface area is also one of the reasons why it is difficult to prepare pellets from vanadia-titania magnetite.

Table 3. Specific surface area of the experimental raw materials.

\begin{tabular}{cccc}
\hline Raw Materials & HS & SJY & YT-14 \\
\hline $\operatorname{BET~}\left(\mathrm{m}^{2} / \mathrm{g}\right)$ & 0.3 & 70.2 & 8.2 \\
\hline
\end{tabular}




\subsection{Experimental Methods}

The experimental scheme controls for the amount of the Sijiaying ore added was unchanged at $50 \%$; the dosage of the sea sand ore used was $0 \%, 10 \%, 20 \%, 30 \%$, and $40 \%$, respectively; and the dosage of Yuantong-14 used was 50\%, $40 \%, 30 \%, 20 \%$, and $10 \%$, respectively; and the external dosage of the binder bentonite was $1.5 \%$. The $3 \mathrm{~kg}$ dried mixture in the disc pelletizer was prepared into $10-12.5 \mathrm{~mm}$ qualified green pellets. Approximately $9 \%$ water was added in the pelletizing process, and the green pellets' performance was tested and analyzed. The qualified green pellets were dried in a drying oven at $110^{\circ} \mathrm{C}$ for $180 \mathrm{~min}$. Then, the dried pellets were taken out and put into a muffle furnace for oxidation roasting. The roasting system is shown in Figure 4. The compressive strength of the oxidized pellets was tested by a digital display automatic pellet pressure testing machine (testing 22 sample pellets, removing a maximum and a minimum).

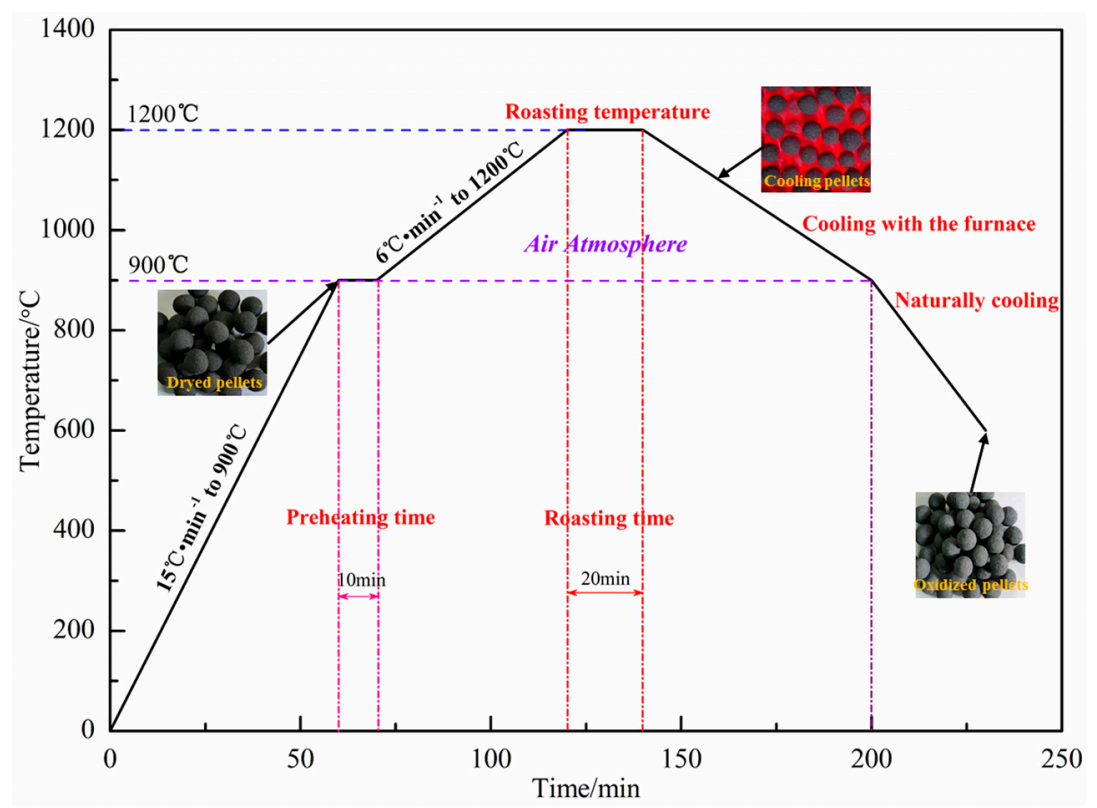

Figure 4. Roasting system of the green pellets.

Eighteen pellets of 10-12.5 mm with uniform shape and no crack were selected as samples for the reduction swelling experiment of the oxidized pellets. After the oxidized pellets were heated to $900{ }^{\circ} \mathrm{C}$ under an inert atmosphere, the reducing atmosphere was adjusted to $10.5 \mathrm{~L} / \mathrm{min}$ nitrogen $\left(\mathrm{N}_{2}\right)$ and $4.5 \mathrm{~L} / \mathrm{min}$ carbon monoxide $(\mathrm{CO})$. After $60 \mathrm{~min}$ of reduction, the pellets were cooled to ambient temperature under an inert atmosphere. Formula (1) was used to calculate the volume of pellets before and after reduction swelling, and Formula (2) was used to calculate the reduction swelling index (RSI), expressed as a percentage of volume:

$$
\begin{gathered}
V=\frac{4}{3} \pi\left(\frac{D}{2}\right)^{3} \\
R S I=\frac{V_{1}-V_{0}}{V_{0}} \times 100 \%
\end{gathered}
$$

where $D$ is the average diameter of the sample $(\mathrm{mm}) ; V_{0}$ is the average volume of the sample before reduction $\left(\mathrm{mm}^{3}\right) ; V_{1}$ is the average volume of the sample after reduction $\left(\mathrm{mm}^{3}\right)$; and $R S I$ is the reduction swelling index (\%).

Five hundred grams of pellets were selected as the sample for the reduction experiment. After the oxidized pellets were heated to $900{ }^{\circ} \mathrm{C}$ under an inert atmosphere, the reducing atmosphere was adjusted to $10.5 \mathrm{~L} / \mathrm{min}$ nitrogen $\left(\mathrm{N}_{2}\right)$ and $4.5 \mathrm{~L} / \mathrm{min}$ carbon monoxide (CO). After $180 \mathrm{~min}$ of reduction, the pellets were cooled to ambient temperature under an inert atmosphere. Formula (3) was used to calculate the reduction degree index 
$(R I)$ of pellets after reduction for $180 \mathrm{~min} . \mathrm{Fe}^{3+}$ was taken as the benchmark and expressed as the mass percentage.

$$
R I=\left(\frac{0.111 W_{1}}{0.430 W_{2}}+\frac{m_{0}-m_{1}}{m_{0} \times 0.430 W_{2}} \times 100\right) \times 100 \%
$$

where $m_{0}$ is the mass of the sample before reduction (g); $m_{1}$ is the mass of the sample after 180 min reduction $(\mathrm{g}) ; W_{1}$ is the content of $\mathrm{FeO}$ in the sample before the test (mass\%); $W_{2}$ is the total iron content of the sample before the test (mass\%); and $R I$ is the reduction index $(\%)$.

To better study the effect of the incremental utilization of unground sea sand ore on the consolidation and reduction behavior of vanadia-titania magnetite pellets and the mechanism of action. Atomic Emission Spectrometer (ICP-AES, Optima 8300DV, PerkinElmer, MA, USA) and XRF (ZSXPrimus-II, Rigaku, Japan) were used to analyze the chemical composition of the experimental raw materials and pellets. The particle characteristics of the experimental raw materials were characterized by a laser particle size analyzer (Mastersizer 3000, Malvern, UK) and a specific surface area (NOVA-1200e, Quantachrome, FL, USA). XRD (X'Pert Pro, PANalytical, Almelo, The Netherlands) was used to analyze the phase composition of the experimental raw materials and pellets before and after reduction; SEM (Ultra Plus; Carl Zeiss GmbH, Jena, Germany) was used to detect the microstructure of the sea sand ore, and pellets before and after reduction through the backscattering detector (BSE) and EDS.

\section{Results and Discussion}

\subsection{Effect of Sea Sand Ore Dosage on the Performance of Green Pellets}

\subsubsection{Falling Strength and Moisture of Green Pellets}

The relationship between the dosage of sea sand ore used and the falling strength and moisture of green pellets is shown in Figure 5. The water content of green pellets was basically maintained at about $8 \%$, which was in line with the best moisture of green pellets. The falling strength gradually increased with an increase in the sea sand ore used. Under the condition that the moisture of green pellets was not much different, when the amount of sea sand ore used increased from $0 \%$ to $40 \%$, the falling strength of green pellets increased from 11.63 times/pellet to 28.71 times/pellet, all of which met the requirements of no less than 3-5 times/pellet.

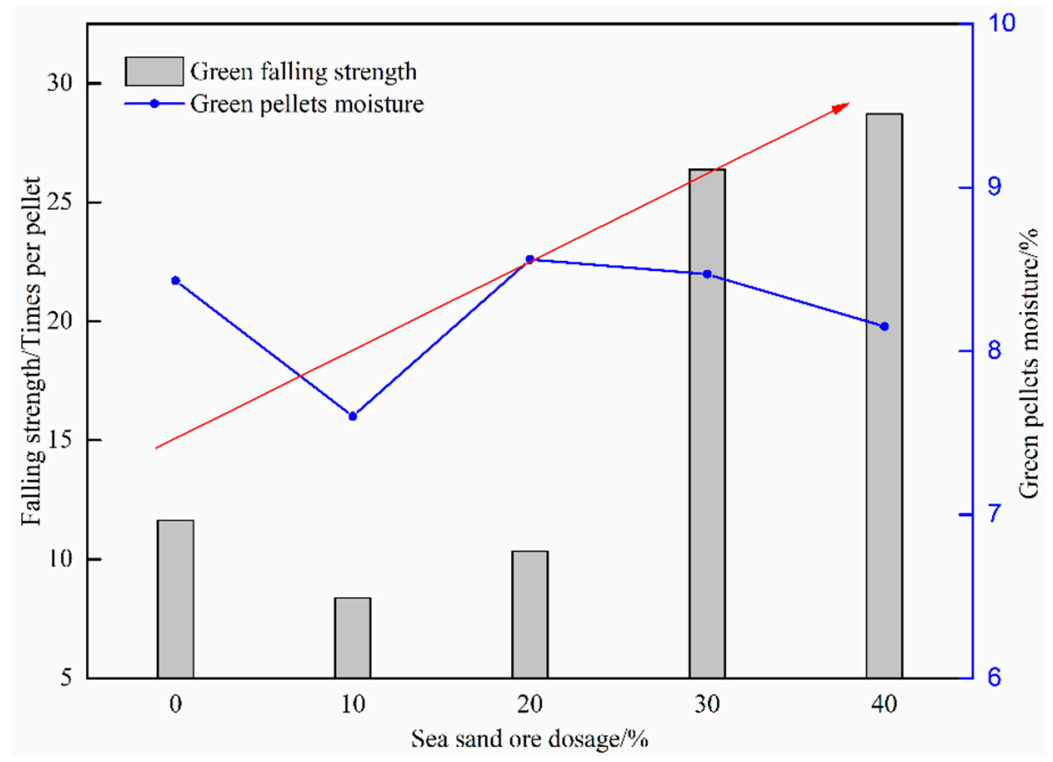

Figure 5. Falling strength and moisture of green pellets with different dosages of sea sand ore. 
For the pellet preparation process, it is not that the particle size of the raw material is as fine as possible. The more fines in the material, the more uneven the wettability, the lower the porosity between the material particles, and segregation will occur. According to the tightest packing theory of the particles in green pellets, that is, the medium particles are embedded between the large particles and the small particles are embedded between the medium particles. In this case, the arrangement of the particles is the tightest, and the strength of green pellets is the highest. With the increase in the amount of sea sand ore added, the fine-grained Yuantong-14 ore gradually decreased. On one hand, the particle size distribution of the raw material particles was more uniform, and the filling of the material particles inside the green pellets was more compact; on the other hand, the coarsegrained sea sand ore played the role of "ball core" and "skeleton" in the process of making pellets, which promoted the formation of the cue ball and the improvement in the green pellets' strength.

\subsubsection{Compressive Strength and Moisture of Green Pellets}

The relationship between the dosage of sea sand ore used and the compressive strength and moisture of green pellets is shown in Figure 6. With increasing sea sand ore dosage, the compressive strength of the green pellets first increased and then decreased. When the dosage of sea sand ore used was $10 \%$, the compressive strength of green pellets was up to $15.69 \mathrm{~N} /$ pellet, and when the dosage of sea sand ore was $40 \%$, the compressive strength of green pellets decreased to $8.41 \mathrm{~N} /$ pellet. The compressive strength of the green pellets was mainly through the combined action of capillary gravitation energy, chemical energy, and viscous energy. With increasing sea sand ore dosage, the coarse-grained particles increased and the capillary gravitational energy decreased. At the same time, the sea sand ore had a smooth surface with a small specific surface area, and the frictional resistance energy between particles decreased. Therefore, the compressive strength of green pellets gradually decreased with increasing sea sand ore dosage.

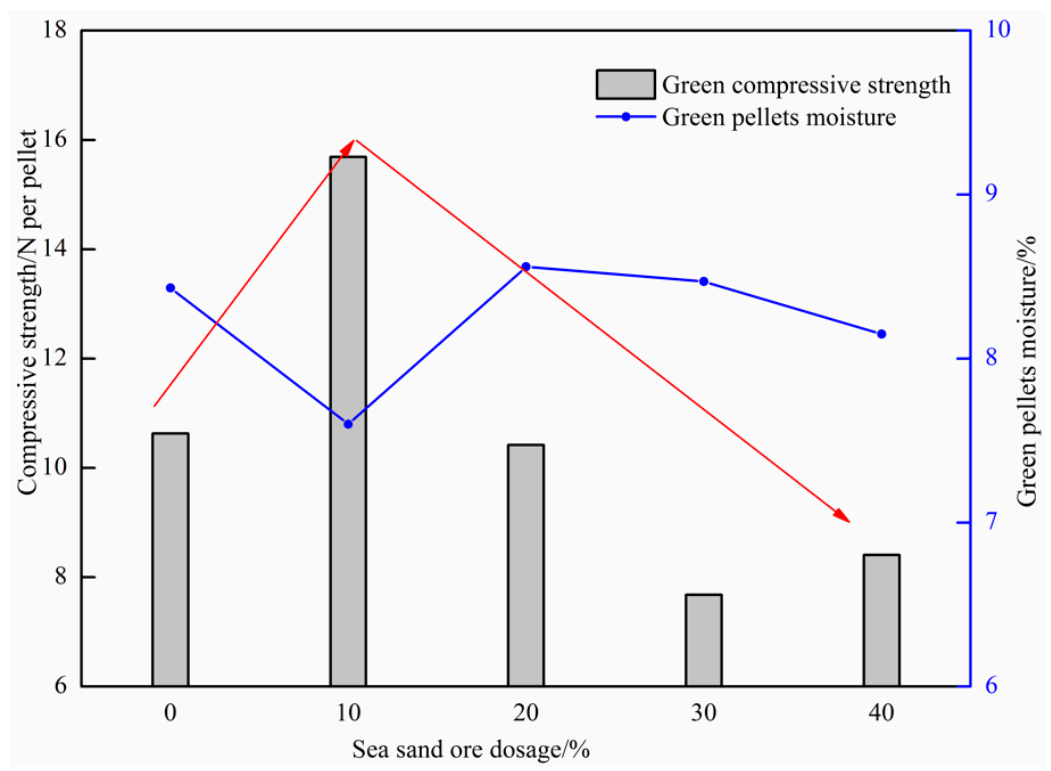

Figure 6. Compressive strength and moisture of the green pellets with different dosages of sea sand ore used.

\subsection{Effect of Sea Sand Ore Dosage on the Compressive Strength of Oxidized Pellets}

The influence of the dosage of sea sand ore on the compressive strength of oxidized pellets is shown in Figure 7. With increasing sea sand ore dosage, the compressive strength of oxidized pellets gradually increased from $2505 \mathrm{~N} /$ pellet to $3146 \mathrm{~N} /$ pellet, which all met the actual production requirements of the enterprise. Within a certain range of sea sand ore addition, with increasing sea sand ore dosage, the compressive strength of oxidized pellets 
was enhanced to a certain extent, but it was still lower than the compressive strength of the pellets without sea sand ore.

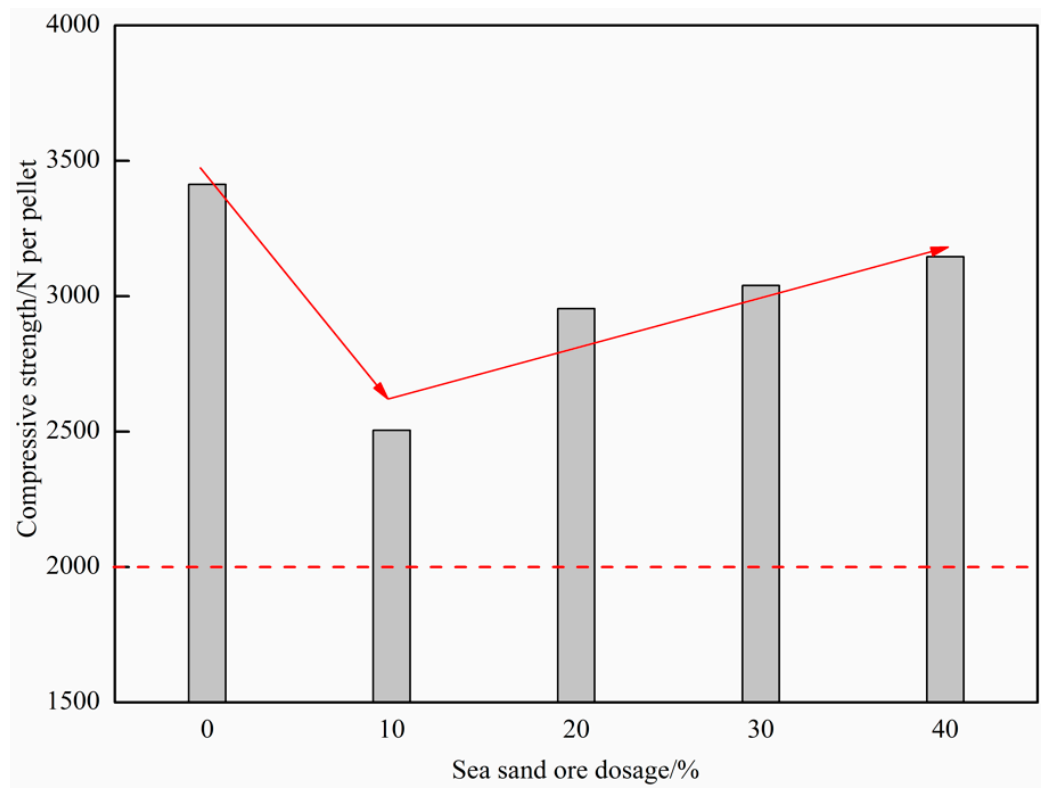

Figure 7. Compressive strength of oxidized pellets with different dosages of sea sand ore.

XRD was used to analyze the oxidized pellets with $0 \%, 20 \%$, and $40 \%$ sea sand ore added, and the results are shown in Figure 8. The oxidized pellets were mainly composed of hematite, ilmenite, silicate, and titanium dioxide. Among the three types of oxidized pellets, $\mathrm{Fe}$ was mainly present in $\mathrm{Fe}_{2} \mathrm{O}_{3}$ and $\mathrm{FeTiO}_{3}$, and Ti was mainly present in $\mathrm{FeTiO}_{3}$. When sea sand ore increased to $40 \%, \mathrm{TiO}_{2}$ was formed. In addition, the silicate phase was mainly $\mathrm{MgAl}_{2} \mathrm{Si}_{4} \mathrm{O}_{12}$ in oxidized pellets without sea sand ore; with increasing sea sand ore dosage, the silicate phase changed to $\mathrm{Al}_{2} \mathrm{SiO}_{5}$.

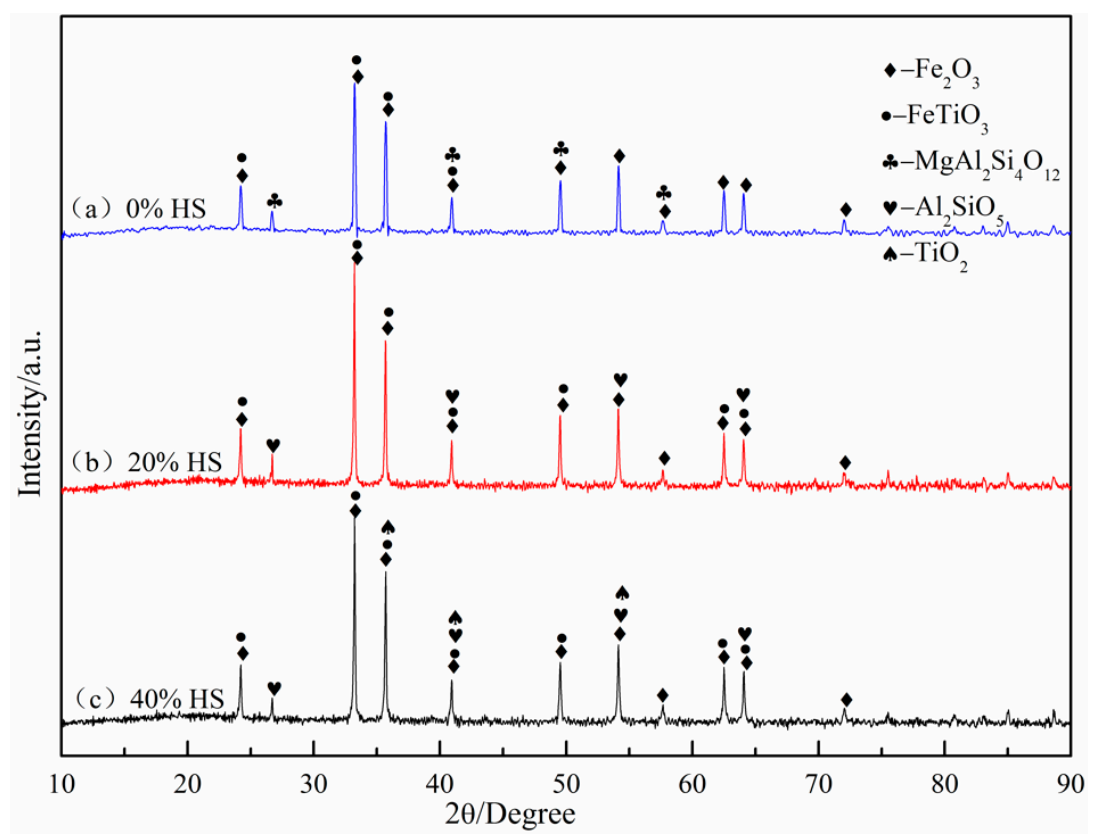

Figure 8. X-ray diffraction analysis of oxidized pellets with different dosages of sea sand ore.

The compressive strength of pellets was mainly determined by the internal microstructure of pellets in the processes of oxidative roasting and the consolidation of pellets. To further explore the change law of the compressive strength of sea sand ore pellets, SEM was 
used to analyze the microscopic morphology of the pellets, and the results are shown in Figure 9. The particle size distribution in the pellets was relatively uniform, the oxidation speed was relatively fast, and the hematite was evenly distributed, which avoided the reaction with $\mathrm{SiO}_{2}$ to form low-strength silicate system compounds such as iron olivine. Therefore, the compressive strength of the oxidized pellets without sea sand ore was higher. As the amount of sea sand ore used increased, the particles inside the pellets appeared as coarser block particles, and the silicate composition gradually increased. Comparing Figure $9 b, c$, it can be seen that with increasing sea sand ore dosage, the particle size distribution in the pellet gradually tended to be uniform, and the holes gradually became smaller. As a result, the compressive strength of pellets gradually increased with increasing sea sand ore dosage.
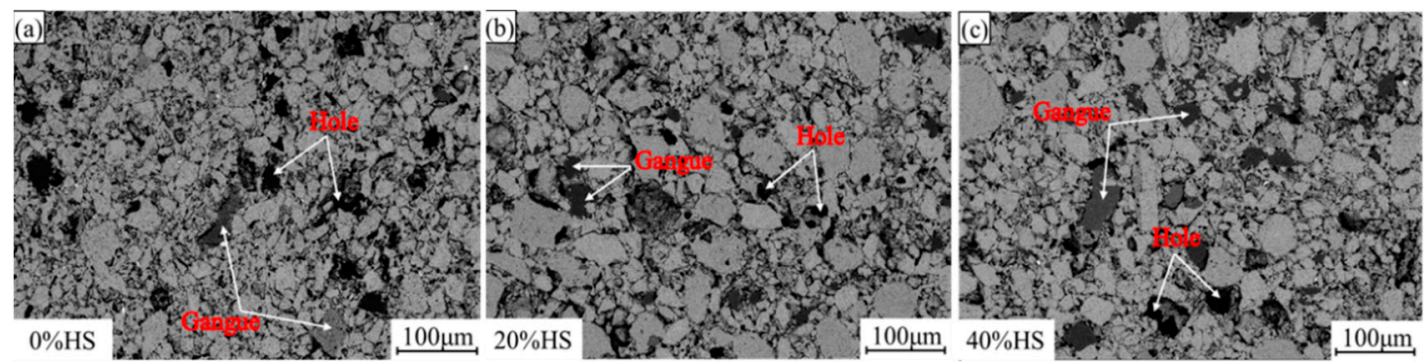

Figure 9. Scanning electron microscopy (SEM) diagrams of the oxidized pellets with different dosages of sea sand ore: (a) 0\% HS; (b) 20\% HS; (c) $40 \%$ HS.

EDS and surface scanning were used to analyze the chemical composition of the internal mineral phases of the oxidized pellets with the additive amount of $40 \%$ sea sand ore, and the results are shown in Figures 10 and 11. Combined with SEM-EDS and surface scanning analysis, it was found that the oxidized pellets of sea sand ore were mainly composed of hematite, ilmenite, silicate, silica, and calcium phosphate. The bright area A was mainly the hematite phase and a small amount of solid solution oxides such as Ti and $\mathrm{V}$; the bright gray area $\mathrm{B}$ was the ilmenite phase containing a small amount of elements such as $\mathrm{Mg}$ and $\mathrm{V}$; the dark gray area $\mathrm{C}$ mainly contained the silicate phase of $\mathrm{Ca}, \mathrm{Mg}, \mathrm{Al}$, and a small amount of $\mathrm{Fe}, \mathrm{Ti}, \mathrm{V}$; the black area $\mathrm{D}$ was oxides such as gangue $\mathrm{SiO}_{2}$; and the light gray area $\mathrm{E}$ was mainly slag phase materials such as calcium phosphate.
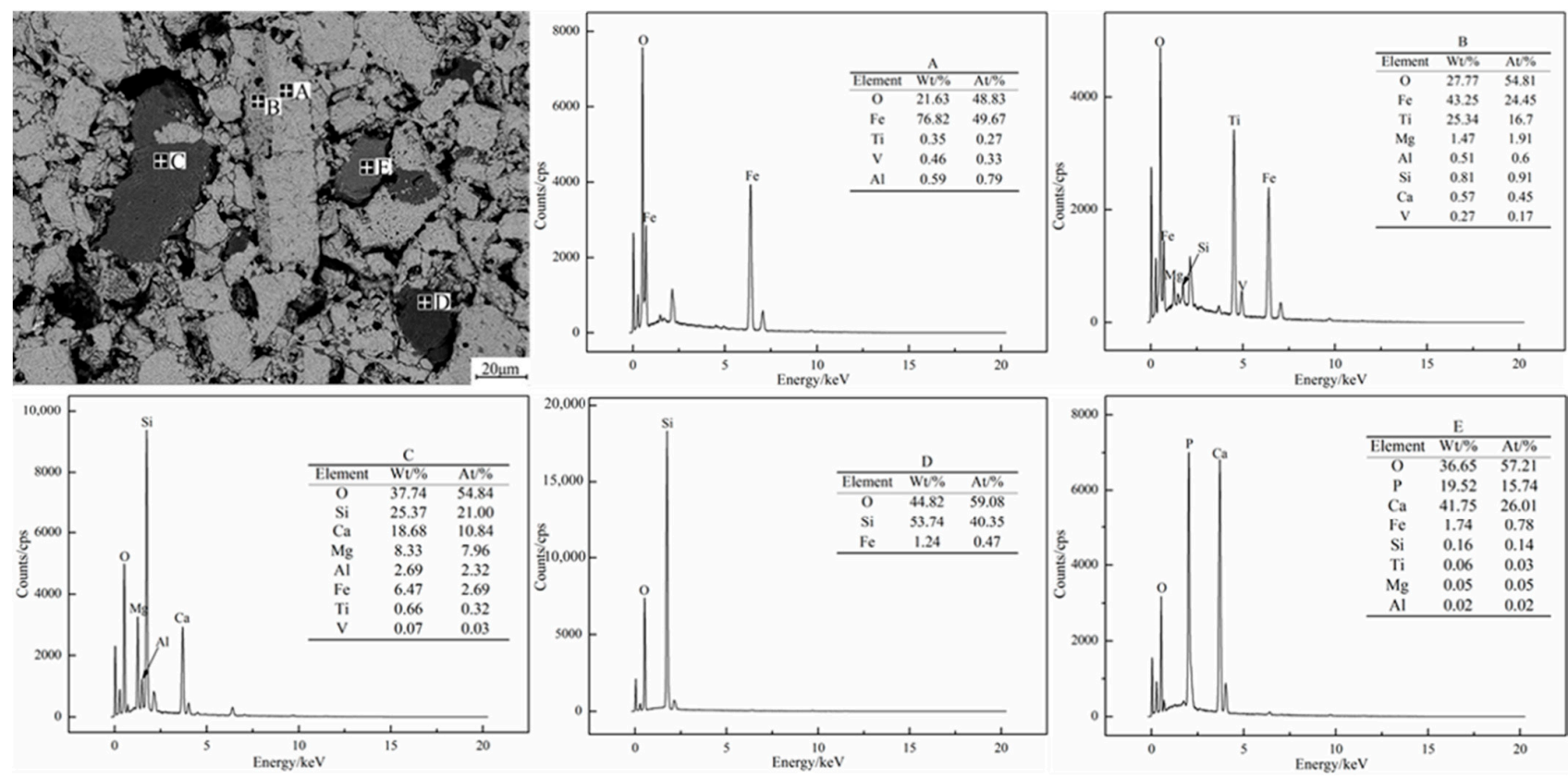

Figure 10. Energy dispersive spectrometer (EDS) graph of oxidized pellets with $40 \%$ sea sand ore. 

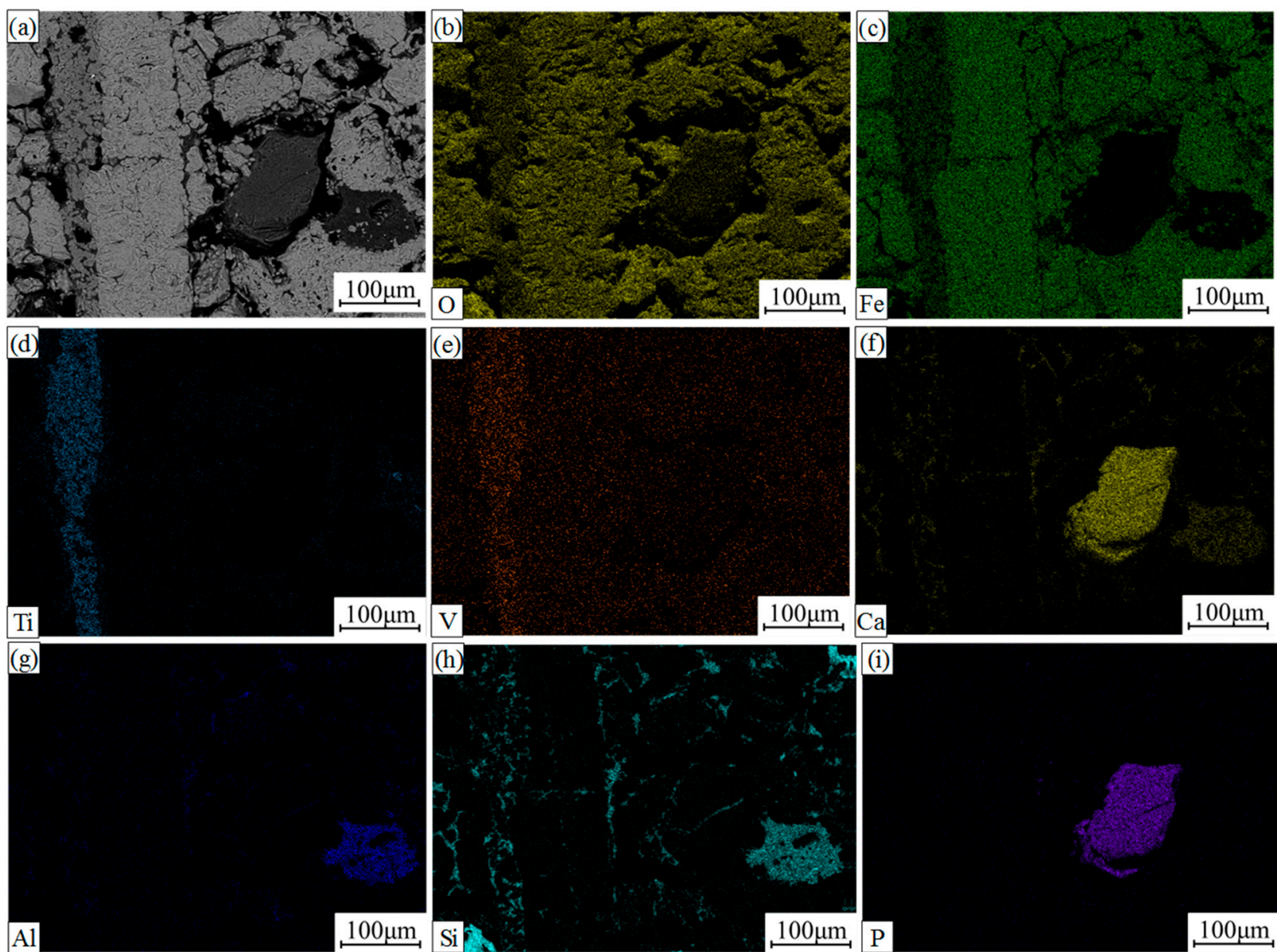

$100 \mu \mathrm{m}$ $100 \mu \mathrm{m}$
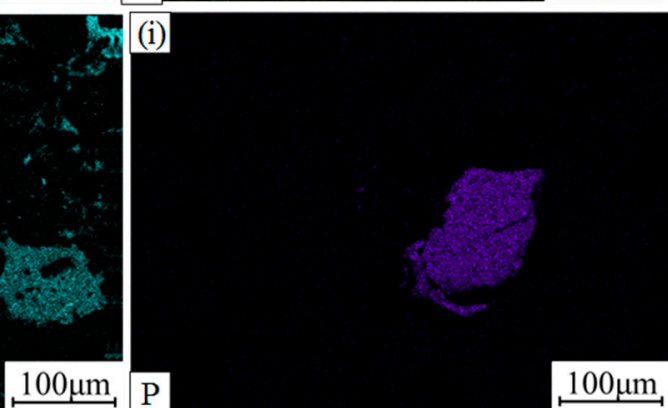

Figure 11. Element distributions of the oxidized pellets with $40 \%$ sea sand ore. (a) Electronic image; (b) $\mathrm{O}$; (c) $\mathrm{Fe}$; (d) Ti; (e) $\mathrm{V}$; (f) $\mathrm{Ca}$; (g) $\mathrm{Al}$; (h) Si; (i) P.

\subsection{Effect of Sea Sand Ore Dosage on Reduction Swelling Index}

The effect of the usage amount of sea sand ore on the reduction swelling index of the oxidized pellets and the compressive strength of the swelling pellets is shown in Figure 12. As the amount of sea sand ore used increased, the reduction swelling index of the oxidized pellets gradually increased, while the compressive strength of the pellets gradually decreased after a reduction in swelling. When the amount of sea sand ore used was $40 \%$, the reduction swelling index of pellets was $16.31 \%$, which can still be used as raw materials for blast furnace ironmaking.

Figure 13 shows the XRD pattern of the sea sand ore oxidized pellets after reduction swelling. With increasing sea sand ore dosage, the porosity between the particles inside the pellets increased, and the gas diffusion rate was fast during the reduction process, which resulted in the accelerated phase transition speed of $\mathrm{Fe}_{2} \mathrm{O}_{3}-\mathrm{Fe}_{3} \mathrm{O}_{4}$, and the crystal bridge between the hematite grains was quickly destroyed. In addition, with increasing sea sand ore dosage, the silicon content increased, which led to the reduction of part hematite into $\mathrm{Fe}$ and $\mathrm{Fe}_{\mathrm{x}} \mathrm{O}$. However, in the process of reducing wuestite to metallic iron, the catalytic action of alkali metals promoted the growth of metallic iron in a certain direction and produced iron whiskers, which made the volume of the pellets expand, and the reduction swelling index increased. In addition, severe pulverization happened after reduction swelling, and it is difficult to ensure the crystalline strength between the pellet particles simply by relying on the iron oxide recrystallization connection. Therefore, the compressive strength of the pellets after reduction swelling decreased. 


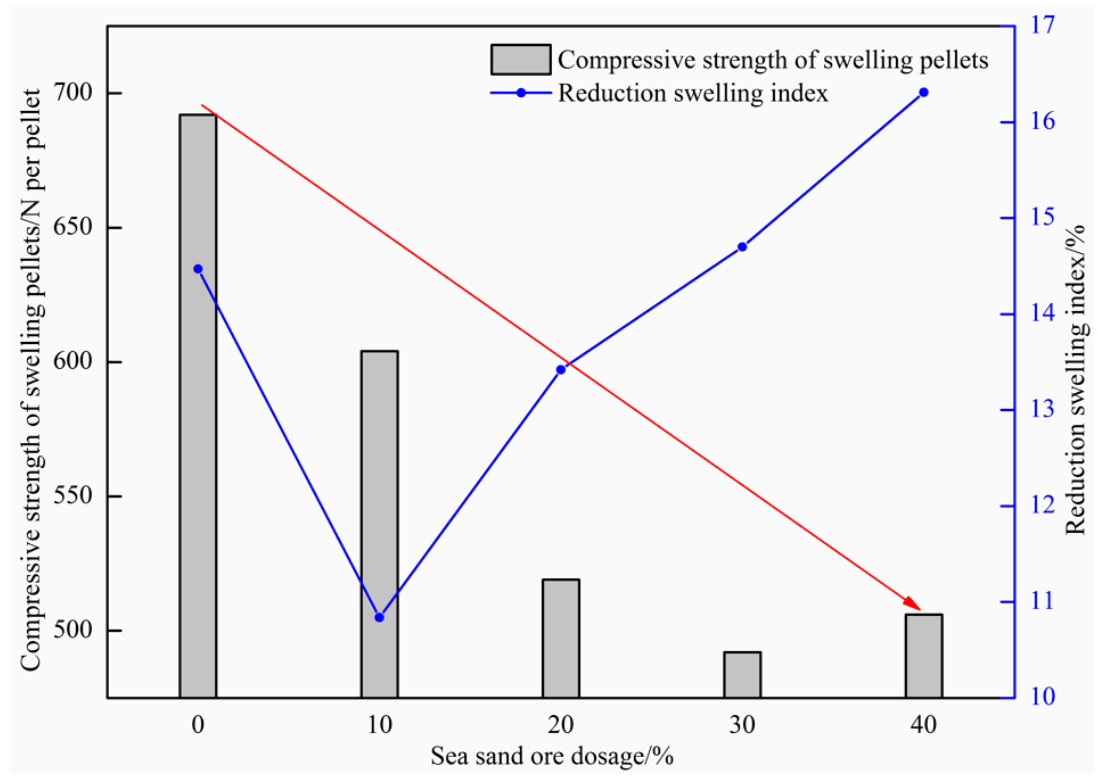

Figure 12. Effect of sea sand ore dosage on the reduction swelling index of the oxidized pellets and compressive strength of the swelling pellets.

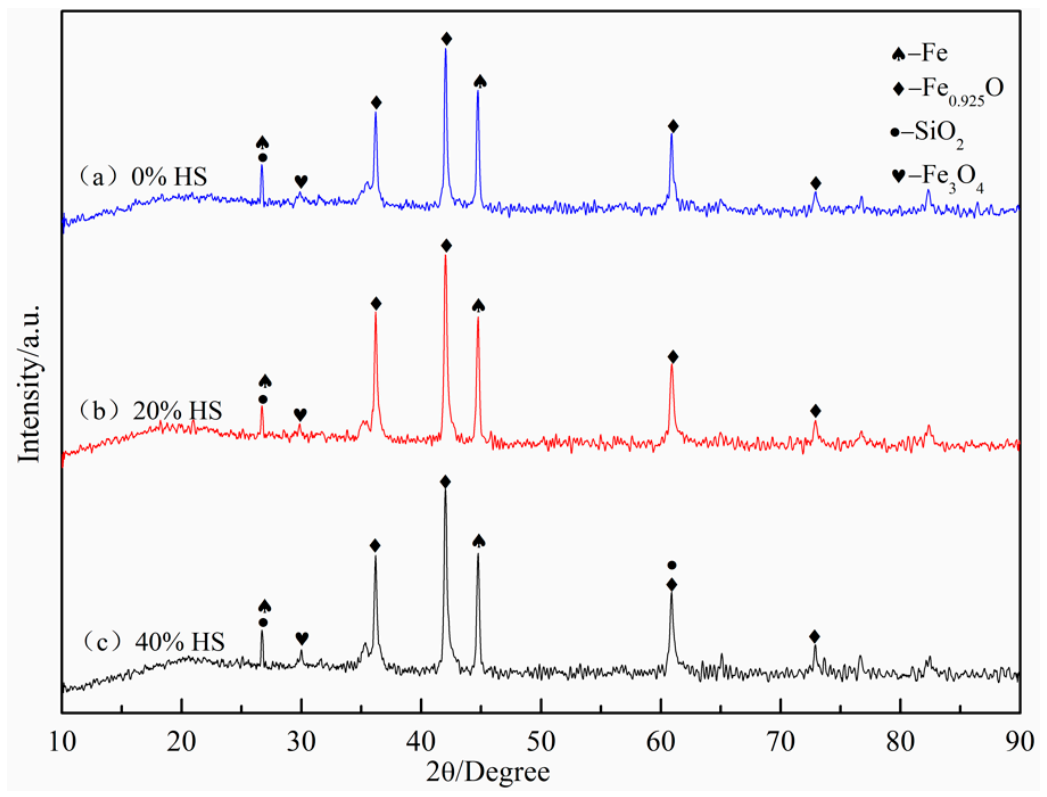

Figure 13. XRD pattern of the oxidized pellets after reduction swelling with different dosages of sea sand ore.

\subsection{Effect of Sea Sand Ore Dosage on the Reduction Degree of Oxidized Pellets}

The influence of sea sand ore dosage on the reduction degree of oxidized pellets and the compressive strength of pellets after reduction is shown in Figure 14. Combining the analysis of the change curve of the reduction degree with the extension of reduction time in Figure 15. It was found that the reduction degree of pellets decreased with increasing sea sand ore dosage. When the amount of sea sand ore used was $40 \%$, the reduction degree of sea sand ore pellets was only $60.06 \%$, and the compressive strength of reduced pellets was $612 \mathrm{~N} /$ pellet. In addition, as the amount of sea sand ore used increased, the reduction rate of the pellets gradually decreased, and the reduction time to a certain reduction degree was gradually prolonged. The main reason was that the sea sand ore was a vanadia-titania ore, and the pellets contained valuable elements such as Ti and V, which are difficult to reduce and resulted in a decrease in the reduction rate and a reduction in the reduction degree. 


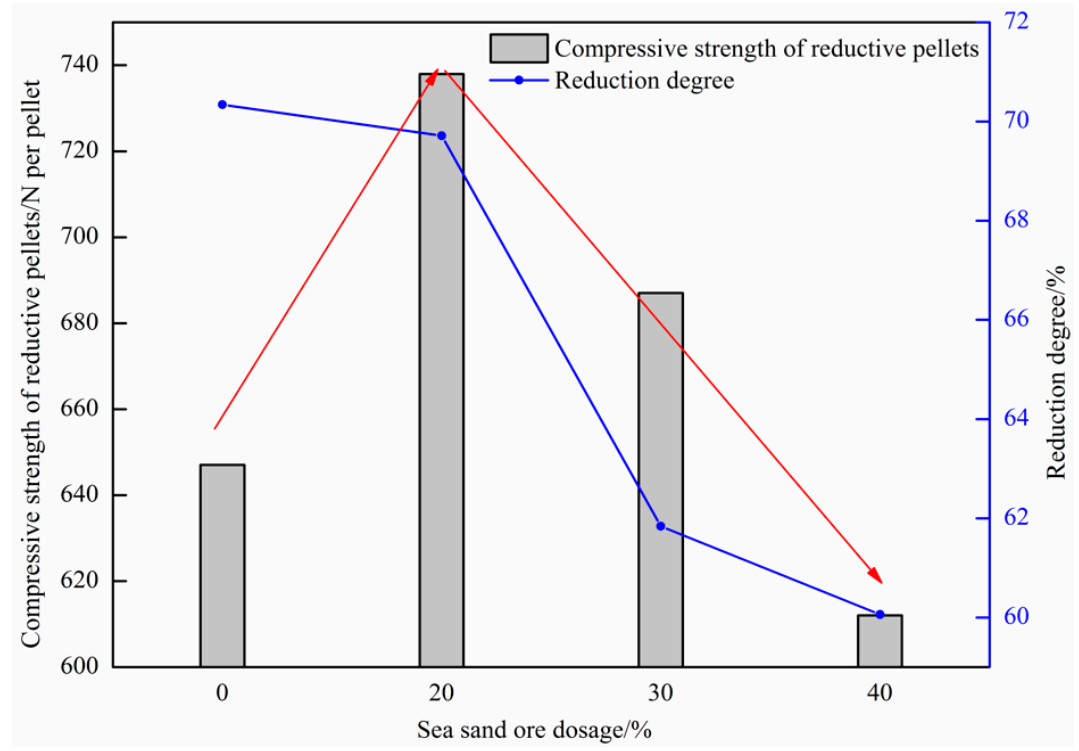

Figure 14. Effect of the sea sand ore dosage on the reduction degree of the oxidized pellets and the compressive strength of the reductive pellets.

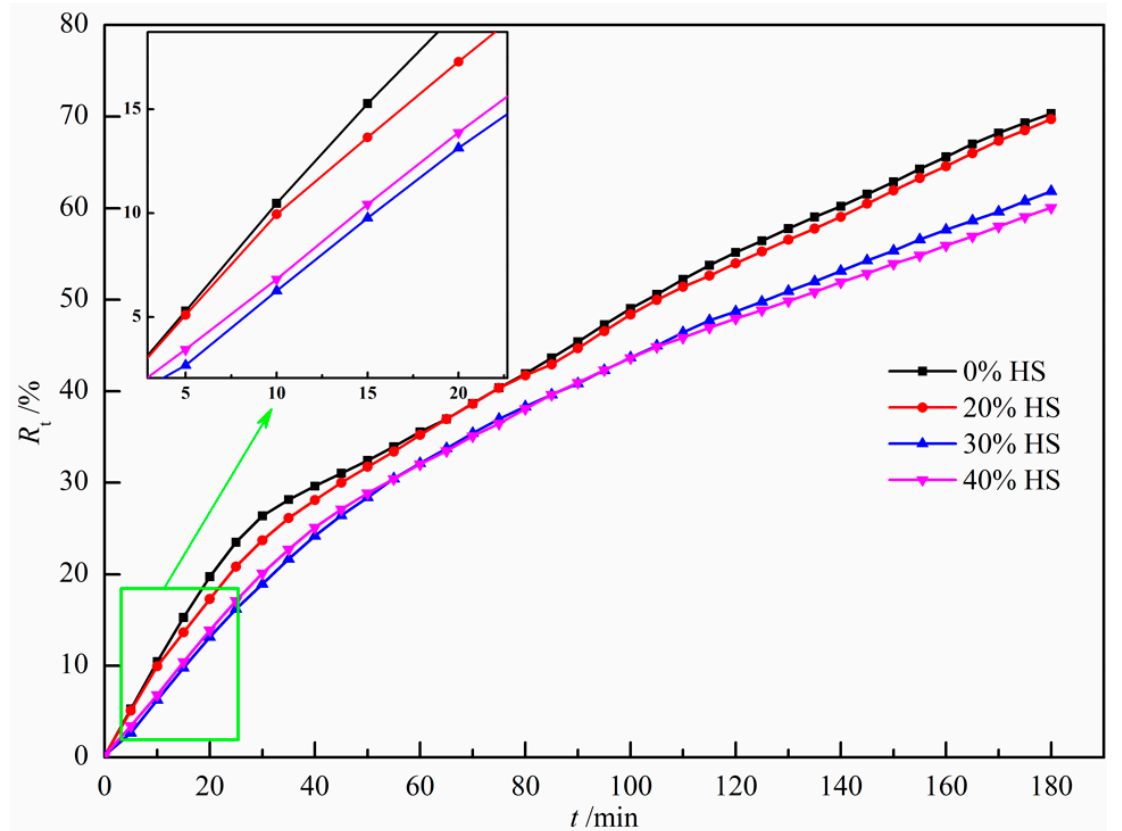

Figure 15. The degree of reduction at different reduction times.

Figure 16 shows the XRD pattern of the oxidized pellets with sea sand ore reduced at $900{ }^{\circ} \mathrm{C}$ for $3 \mathrm{~h}$. The reductive phases of the pellets with sea sand ore were mainly metal iron, wuestite, silica, and silicate. Based on the relationship between $\Delta G^{\theta}$ and $T$ in the reduction process of oxidized pellets with sea sand ore in Figure 17, the main reactions that occur in the reduction process of pellets with sea sand ore are shown in Formulas (4)-(9):

$$
\begin{gathered}
\mathrm{FeTiO}_{3}+\mathrm{CO}=\mathrm{Fe}+\mathrm{TiO}_{2}+\mathrm{CO}_{2} \\
2 \mathrm{FeTiO}_{3}+\mathrm{CO}=\mathrm{Fe}+\mathrm{FeTi}_{2} \mathrm{O}_{5}+\mathrm{CO}_{2} \\
1.5 \mathrm{FeTi}_{2} \mathrm{O}_{5}+2.5 \mathrm{CO}=1.5 \mathrm{Fe}+\mathrm{Ti}_{3} \mathrm{O}_{5}+2.5 \mathrm{CO}_{2} \\
3 \mathrm{Fe}_{2} \mathrm{O}_{3}+\mathrm{CO}=2 \mathrm{Fe}_{3} \mathrm{O}_{4}+\mathrm{CO}_{2} \\
\mathrm{Fe}_{3} \mathrm{O}_{4}+\mathrm{CO}=3 \mathrm{FeO}+\mathrm{CO}_{2}
\end{gathered}
$$


$\mathrm{FeO}+\mathrm{CO}=\mathrm{Fe}+\mathrm{CO}_{2}$

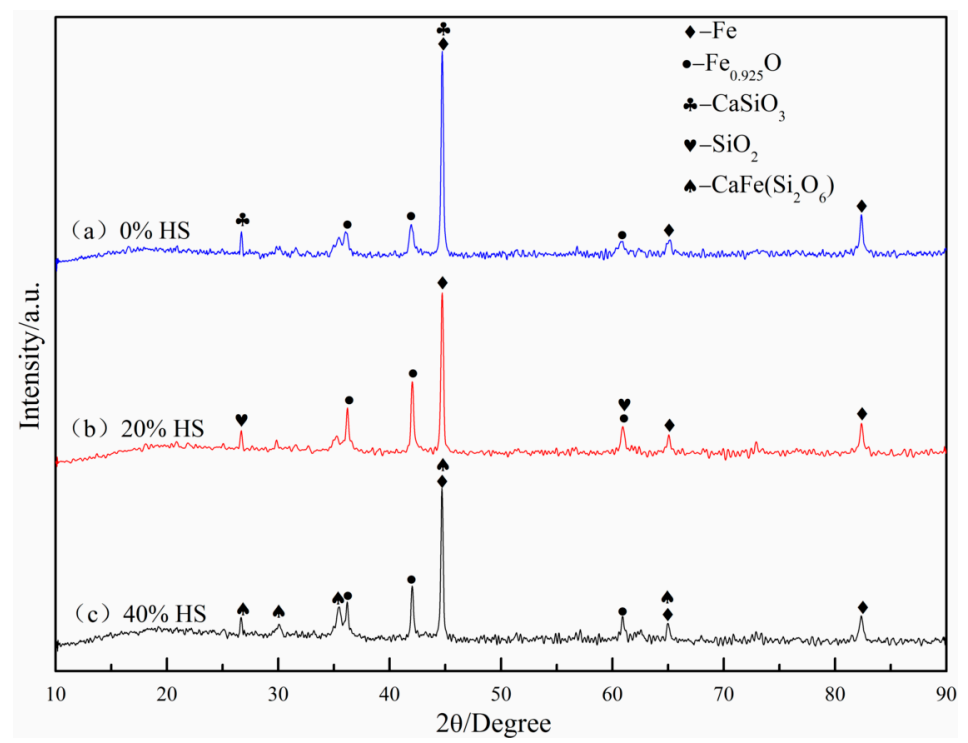

Figure 16. X-ray diffraction analysis of the oxidized pellets with sea sand ore reduced at $900{ }^{\circ} \mathrm{C}$ for $3 \mathrm{~h}$.

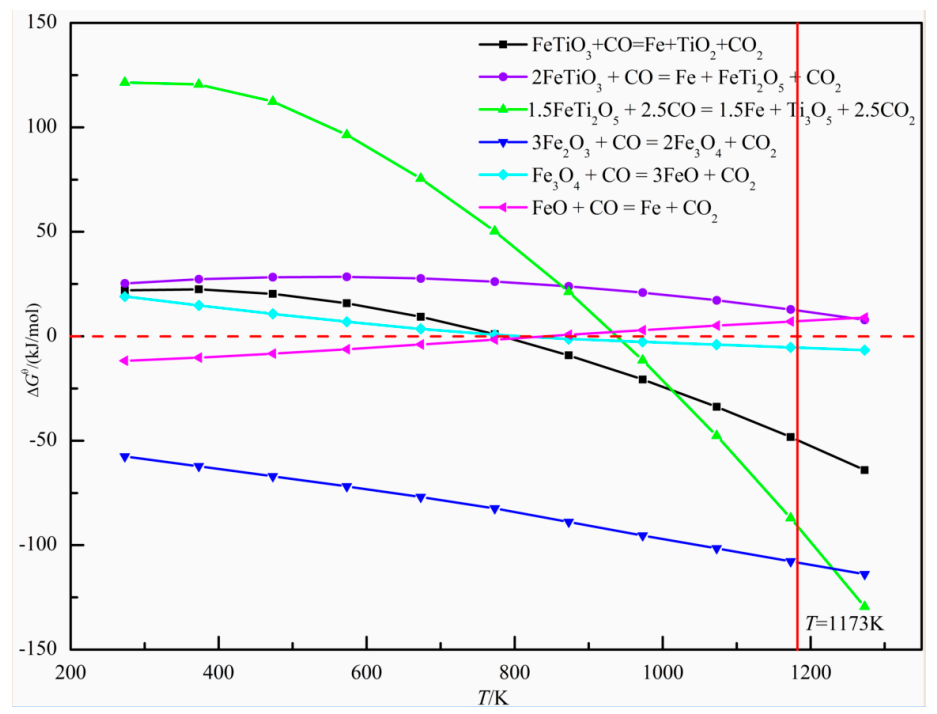

Figure 17. Relationship between $\Delta G^{\theta}$ and $T$ in the reduction process of oxidized pellets with the sea sand ore.

With increasing sea sand ore dosage, the $\mathrm{FeTiO}_{3}$ content in oxidized pellets increased, and the reduction of $\mathrm{FeTiO}_{3}$ was mainly according to Formulas (4)-(6). It can be observed from Figure 17 that when the reduction temperature was $1173 \mathrm{~K}$, the occurrence of Reaction (5) was still difficult. Therefore, the reduction product of $\mathrm{FeTiO}_{3}$ was metallic iron, but not $\mathrm{FeTi}_{2} \mathrm{O}_{5}$. The reduction of hematite was mainly the process of reducing hematite to magnetite in accordance with Formula (7), reducing magnetite to ferrous oxide with Formula (8), and reducing the ferrous oxide to metallic iron with Formula (9). Therefore, with the increase in sea sand ore used, the $\mathrm{FeTiO}_{3}$ content in oxidized pellets increased, but the reduction of $\mathrm{FeTiO}_{3}$ in oxidized pellets was limited, so the reduction degree of the pellets gradually decreased.

Figure 18 shows the SEM images of the oxidized pellets with different dosages of sea sand ore after reduction at $900{ }^{\circ} \mathrm{C}$ for $3 \mathrm{~h}$ and Figure 19 shows the EDS images of oxidized pellets with $40 \%$ sea sand ore after reduction at $900{ }^{\circ} \mathrm{C}$ for $3 \mathrm{~h}$. The phases in reductive pellets were mainly composed of slag phases such as zone A metallic iron, zone B wuestite, 
zone C ilmenite, zone D silica, and zone E silicate. Among them, the bright white metallic iron phase outer layer was mostly dark gray wuestite, which explains that the reduction of pellets was mainly carried out gradually from the outside to the inside. The ilmenite distributed in dots or layers mostly grew on the outside of the metallic iron and wuestite phase. After reduction, the dark black slag phase was mainly filled around the metal phase. In addition, holes appeared in the pellet after reduction. At the same time, as the amount of sea sand ore used increased, holes inside the pellet gradually increased and became larger, so the compressive strength of the pellets after reduction gradually decreased. In addition, as the amount of sea sand ore used increased, the metallic iron phase of the reductive pellets gradually became smaller, while the wuestite phase gradually became larger. This indicates that with increasing sea sand ore dosage, the reduction rate of the oxidized pellets gradually slowed down and the difficulty in the reduction of the oxidized pellets increased.

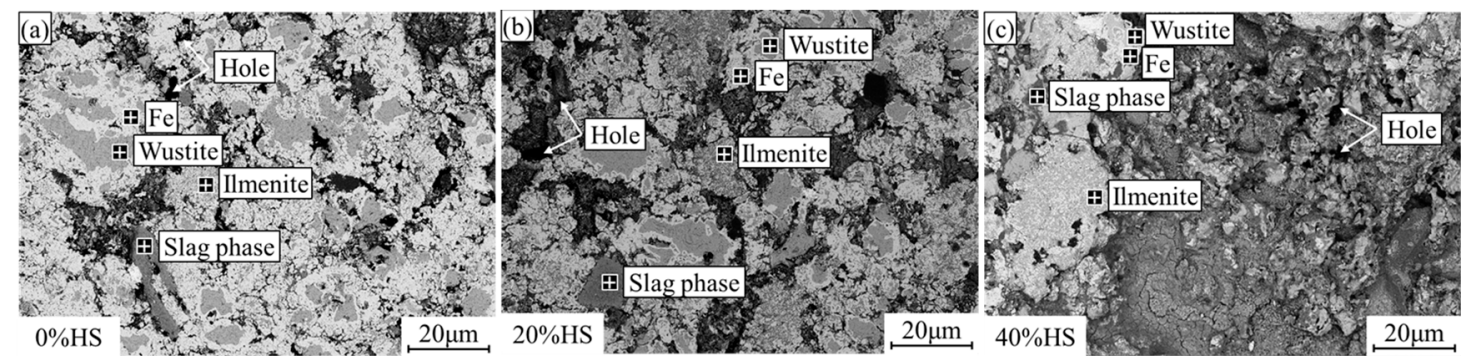

Figure 18. SEM diagrams of the oxidized pellets with the sea sand ore reduced at $900{ }^{\circ} \mathrm{C}$ for $3 \mathrm{~h}$. (a) $0 \% \mathrm{HS}$; (b) $20 \% \mathrm{HS}$; (c) $40 \%$ HS.
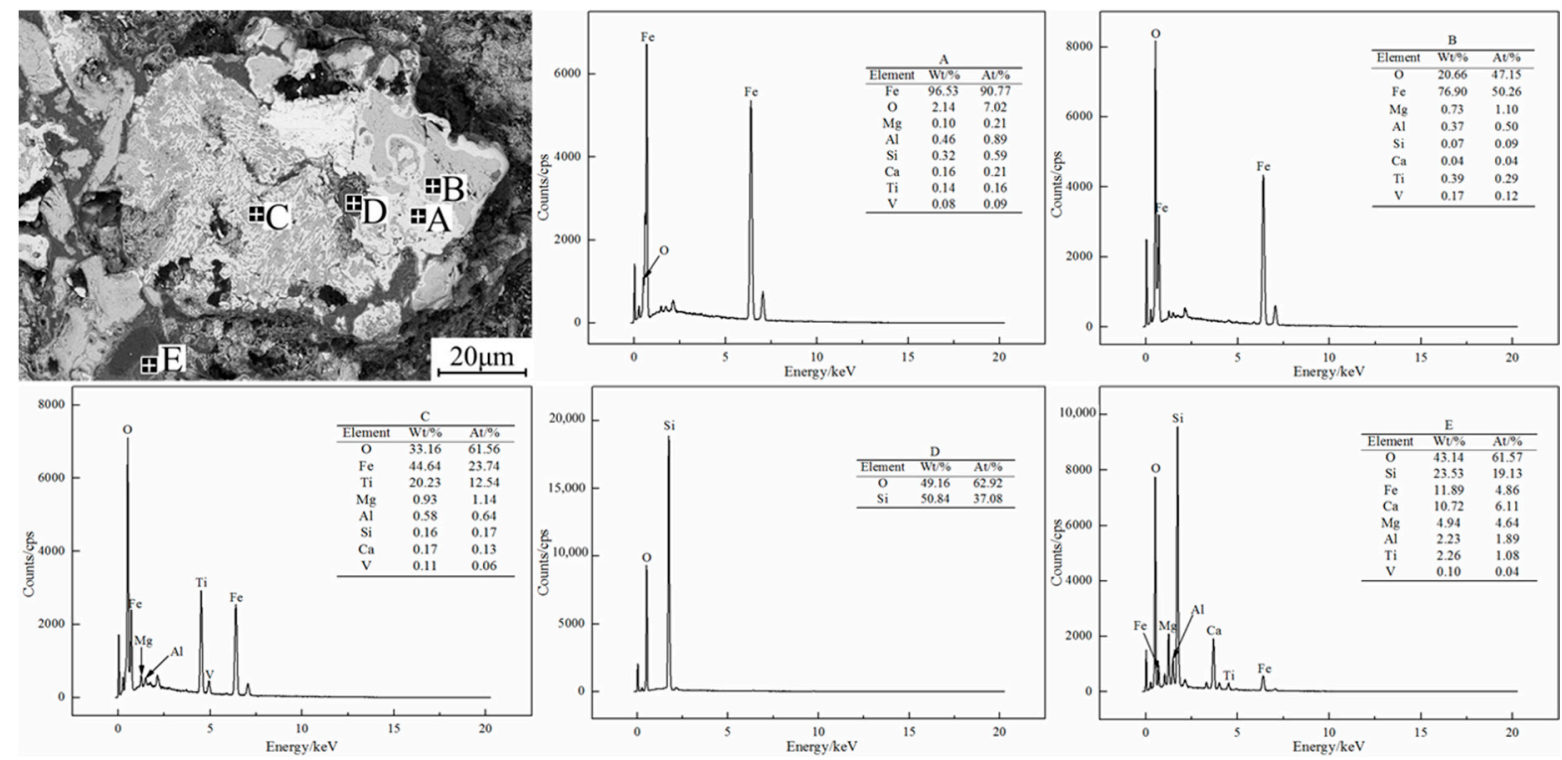

Figure 19. EDS diagrams of the oxidized pellets with $40 \%$ sea sand ore reduced at $900{ }^{\circ} \mathrm{C}$ for $3 \mathrm{~h}$.

Figure 20 shows the elemental distributions of the oxidized pellets with $40 \%$ sea sand ore reduced at $900{ }^{\circ} \mathrm{C}$ for $3 \mathrm{~h}$. It can be seen from the figure that titanium and iron achieved a preliminary separation. Most of the iron existed alone in the form of metallic iron or wuestite, and most of the titanium formed a new phase of ilmenite. There were fewer impurities in the accumulation area of the metallic iron phase; $\mathrm{Ca}, \mathrm{Mg}, \mathrm{Al}$, and $\mathrm{Si}$ were mainly concentrated in the slag phase, which achieved the separation of iron and gangue. 


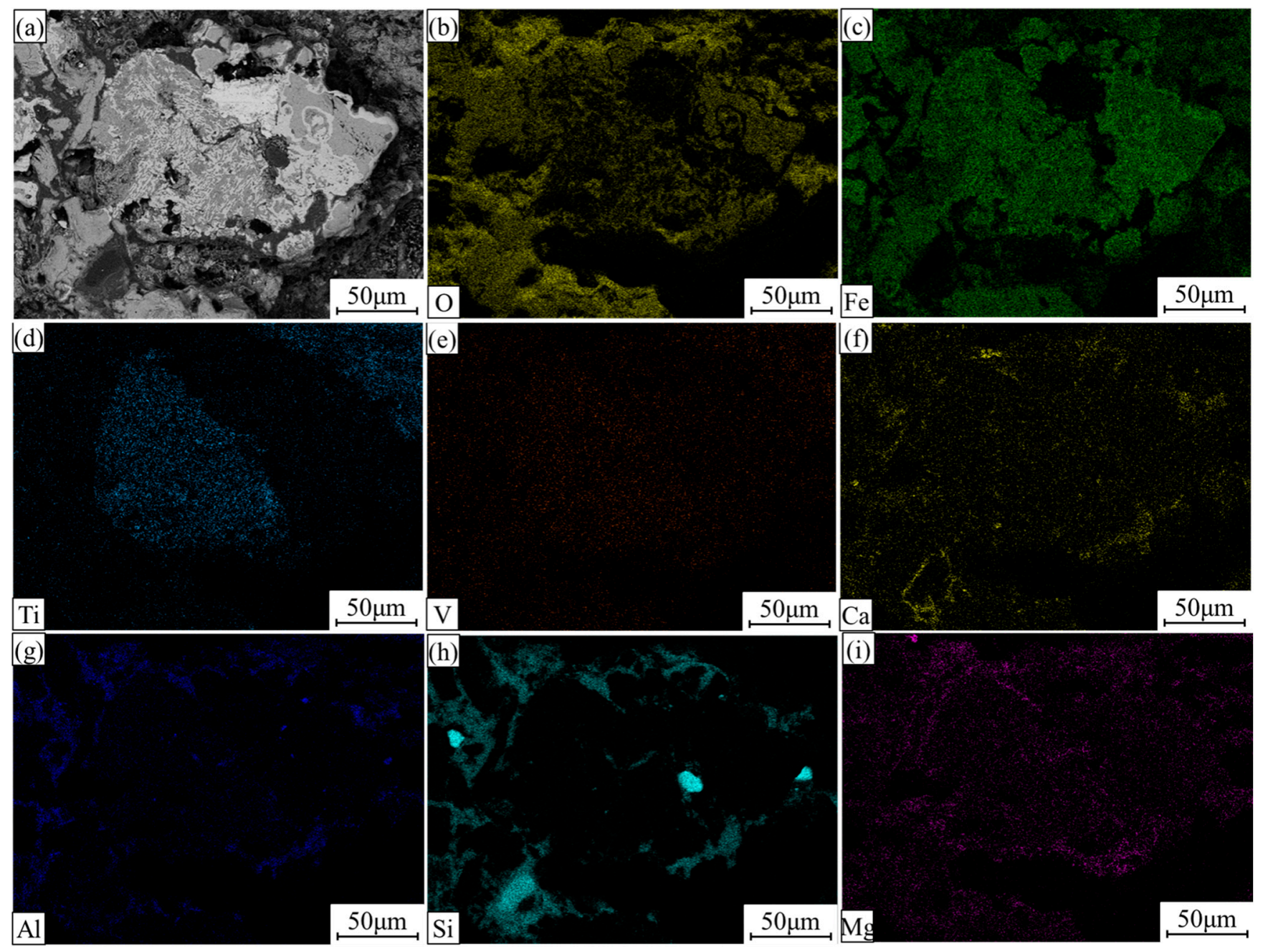

Figure 20. Elemental distributions of the oxidized pellets with $40 \%$ sea sand ore reduced at $900{ }^{\circ} \mathrm{C}$ for $3 \mathrm{~h}$. (a) Electronic image; (b) $\mathrm{O}$; (c) $\mathrm{Fe}$; (d) $\mathrm{Ti}$; (e) $\mathrm{V}$; (f) $\mathrm{Ca}$; (g) $\mathrm{Al}$; (h) $\mathrm{Si}$; (i) $\mathrm{Mg}$.

\section{Conclusions}

According to the principle of optimizing ore blending, the grinding process was eliminated in the research. Vanadia-titania magnetite pellets were prepared by the incremental utilization of unground sea sand ore and the addition of Sijiaying and Yuantong-14 ore as auxiliary materials. The influence of sea sand ore on the compressive strength, falling strength, and reduction performance of the oxidized pellets was studied, and the influencing mechanism was explored. The main conclusions are as follows:

(1) The moisture of green pellets with sea sand ore did not change much, and basically maintained at about $8 \%$, which was in line with the best moisture for the preparation of green pellets. The falling strength of green pellets and the compressive strength of the oxidized pellets gradually increased with the increase in sea sand ore dosage, while the compressive strength of green pellets gradually decreased, but it still met the requirements of blast furnace ironmaking raw material production.

(2) As the amount of sea sand ore used increased, the reduction swelling index of pellets gradually increased, while the compressive strength of the pellets after reduction swelling showed a trend of gradual decline. When the amount of sea sand ore used was $40 \%$, the reduction swelling index of pellets was $16.31 \%$, which can still be used as the raw materials for blast furnace ironmaking.

(3) When the amount of sea sand ore used gradually increased, the reduction of pellets was inhibited, the reduction index decreased, and the compressive strength of pellets 
after reduction also gradually decreased. The microscopic morphology of reductive pellets showed that the reductive pellets were mainly composed of metallic iron, wuestite, ilmenite, and slag phases such as silica and silicate. When the amount of sea sand ore used was $40 \%$, the reduction degree of pellets was $60.06 \%$, and the compressive strength of the reductive pellets was $612 \mathrm{~N} /$ pellet.

\begin{abstract}
Author Contributions: Conceptualization, X.X.; Methodology, H.Y.; Validation, X.X. and H.Y.; Formal analysis, Z.G.; Investigation, G.C.; Resources, X.X.; Data curation, Z.G.; Writing-original draft preparation, Z.X.; Writing-review and editing, Z.X.; Supervision, X.X.; Project administration, X.X.; Funding acquisition, X.X. All authors have read and agreed to the published version of the manuscript.

Funding: This work was supported by the National Natural Science Foundation of China (grant nos. 51674084, 21908020 and U1908226) and the Fundamental Research Funds for the Central Universities (grant no. N182503035).
\end{abstract}

Institutional Review Board Statement: Not applicable.

Informed Consent Statement: Not applicable.

Data Availability Statement: Not applicable.

Conflicts of Interest: The authors declare no conflict of interest.

\title{
References
}

1. Hu, T.Y.; Sun, T.C.; Kou, J.; Geng, C.; Wang, X.; Chen, C. Recovering titanium and iron by co-reduction roasting of seaside titanomagnetite and blast furnace dust. Int. J. Miner. Process. 2017, 165, 28-33. [CrossRef]

2. Cheng, G.J.; Liu, J.X.; Liu, Z.G.; Chu, M.-S.; Xue, X.-X. Non-isothermal reduction mechanism and kinetics of high chromium vanadium-titanium magnetite pellets. Ironmak. Steelmak. 2015, 42, 17-26. [CrossRef]

3. Cheng, G.J.; Xue, X.X.; Gao, Z.X.; Jiang, T.; Yang, H.; Duan, P.N. Effect of $\mathrm{Cr}_{2} \mathrm{O}_{3}$ on the Reduction and Smelting Mechanism of High-Chromium Vanadium-titanium Magnetite Pellets. ISIJ Int. 2016, 56, 1938-1947. [CrossRef]

4. Cheng, G.J.; Xue, X.X.; Jiang, T.; Duan, P. Effect of $\mathrm{TiO}_{2}$ on the Crushing Strength and Smelting Mechanism of High-Chromium Vanadium-Titanium Magnetite Pellets. Metall. Mater. Trans. B 2016, 47, 1713-1726. [CrossRef]

5. Wright, J.B. Iron-titanium oxides in Some New Zealand ironsands. N. Z. J. Geol. Geophys. 1964, 7, 424-444. [CrossRef]

6. Wright, J.B. Heating experiments on New Zealand ironsands and the presence of pseudobrookite. N. Z. J. Geol. Geophys. 1967, 10, 659-665. [CrossRef]

7. Wright, J.B.; Lovering, J.F. Electron-probe micro-analysis of the iron-titanium oxides in some New Zealand ironsands. Miner. Mag. 1965, 35, 604-621. [CrossRef]

8. Wang, Z.; Pinson, D.; Chew, S.; Rogers, H.; Monaghan, B.J.; Pownceby, M.I.; Webster, N.A.S.; Zhang, G. Behavior of New Zealand Ironsand During Iron Ore Sintering. Metall. Mater. Trans. B 2016, 47, 330-343. [CrossRef]

9. Zhang, Y.P.; Zhang, J.L.; Wang, Z.Y.; Liu, Z.J.; Liu, X.L. Sintering characteristics of titanium sands after grinding and its influence mechanism on the quality of sinter. Chin. J. Eng. 2016, 38, 468-475.

10. Cheng, G.J.; Xing, Z.X.; Yang, H.; Xue, X.-X. Effects of High Proportion Unground Sea Sand Ore on the Preparation Process and Reduction Performance of Oxidized Pellets. Minerals 2021, 11, 87. [CrossRef]

11. Xing, Z.X.; Cheng, G.J.; Gao, Z.X.; Yang, H.; Xue, X.-X. Optimization of experimental conditions on preparation of oxidized pellets with New Zealand sea sand ore. Metall. Res. Technol. 2020, 117, 411-421. [CrossRef]

12. Xing, Z.X.; Cheng, G.J.; Yang, H.; Xue, X.-X. xperimental Research on Preparation of Oxidized Pellets with High Proportion Sea Sand Mine. In Proceedings of the 12th CSM Steel Congress, Beijing, China, 15-16 October 2019; Volume 10, pp. 1-4.

13. Longbottom, R.J.; Ingham, B.; Reid, M.H.; Studer, A.J.; Bumby, C.; Monaghan, B.J. In situ neutron diffraction study of the reduction of New Zealand ironsands in dilute hydrogen mixtures. Miner. Process. Extr. Met. 1937, 19, 227-244. [CrossRef]

14. Xu, L.B.; Zhou, M.S.; Liu, J.; Han, S.F.; Li, Z.; Zhai, L.W.; Zhang, H. Sintering Characteristics of New Zealand's Iron Sands. Min. Metall. Eng. 2015, 35, 91-94.

15. Wang, Z.D.; Shi, J.; Song, H.Q. Sintering experimental of proportioning of New Zealand iron ore concentrates in Panzhihua I\&S Co. Sinter. Pelletizing 1999, 24, 19-21.

16. Cai, X.F.; Tian, T.L. Study on sintering characteristics of malaysia sea sand iron ore. Sinter. Pelletizing 2013, 38, 6-8.

17. Li, Z.Q.; Zhang, Y. Smelting process analysis of Vanadium titanium sea sand magnetite in New Zealand. Mod. Metall. 2017, 45, 31-33.

18. Liu, Y.R.; Zhang, J.L.; Wang, Z.Y.; Liu, Z.; Xing, X. Experimental research on the deep reduction-Magnetic separation of ironsand. Chin. J. Eng. 2016, 38, 181-186.

19. Lv, Q.; Wang, W.S.; Jin, Y.C.; Li, F.M.; Gao, F. Influence of New Zealand sea sand proportioning ratio on metallurgical properties of vanadium-titanium-bearing sinter of Cheng Steel. Iron Steel Vanadium Titan. 2010, 31, 80-83. 
20. Hu, B.S.; Liu, H.; Li, L.; Wang, Y.; Li, W.D. Influence of proportioning sea sand iron ore on sintering process. Sinter. Pelletizing 2006, 31, 16-20.

21. Park, E.; Ostrovski, O. Reduction of titania-ferrous ore by carbon monoxide. ISIJ Int. 2003, 43, 1316-1325. [CrossRef]

22. Park, E.; Ostrovski, O. Reduction of Titania-Ferrous Ore by Hydrogen. ISIJ Int. 2004, 44, 999-1005. [CrossRef]

23. Park, E.; Ostrovski, O. Effects of Preoxidation of Titania-Ferrous Ore on the Ore Structure and Reduction Behavior. ISIJ Int. 2004, 44, 74-81. [CrossRef]

24. Longbottom, R.J.; Ostrovski, O.; Park, E. Formation of Cementite from Titanomagnetite Ore. ISIJ Int. 2006, 46, 641-646. [CrossRef]

25. Longbottom, R.J.; Monaghan, B.J.; Nightingale, S.A.; Mathieson, J.G. Strength and bonding in reduced ironsand-coal compacts. Ironmak. Steelmak. 2013, 40, 381-389. [CrossRef]

26. Longbottom, R.J.; Monaghan, B.J.; Mathieson, J.G. Development of a Bonding Phase within Titanomagnetite-Coal Compacts. ISIJ Int. 2013, 53, 1152-1160. [CrossRef]

27. Gao, E.X.; Sun, T.C.; Liu, Z.G.; Geng, C.; Xu, C.-Y. Effect of Sodium Sulfate on Direct Reduction of Beach Titanomagnetite for Separation of Iron and Titanium. J. Iron Steel Res. Int. 2016, 23, 428-433. [CrossRef]

28. Geng, C.; Sun, T.C.; Ma, Y.W.; Xu, C.-Y.; Yang, H.-F. Effects of embedding direct reduction followed by magnetic separation on recovering titanium and iron of beach titanomagnetite concentrate. J. Iron Steel Res. Int. 2017, 24, 156-164. [CrossRef]

29. Zhao, Y.Q.; Sun, T.C.; Zhao, H.Y.; Chen, C.; Wang, X.-P. Effect of reductant type on the embedding direct reduction of beach titanomagnetite concentrate. Int. J. Miner. Metall. Mater. 2019, 26, 152-159. [CrossRef] 